\title{
Three Monetary Forces and an Interpretation
}

\author{
José Villacís González ${ }^{1, *}$ \\ ${ }^{1}$ Universidad CEU-San Pablo, Paseo Juan XXIII, 8, 28040 Madrid, Spain \\ *Correspondence: Universidad CEU-San Pablo, Paseo Juan XXIII, 8, 28040 Madrid, Spain. E-mail: \\ villacis.fhm@ceu.es
}

Received: September 12, 2016 Accepted: October 9, $2016 \quad$ Online Published: October 24, 2016

doi:10.5430/mos.v3n4p53

URL: http://dx.doi.org/10.5430/mos.v3n4p53

\begin{abstract}
There are three monetary phenomena that multiply money and nominal income via the intervention of parameters that are the multipliers: the income multiplier, the money multiplier, and another, which is similar, named the velocity of money. This study aims to integrate them in a single formula and meaning as they constitute the same monetary process. Money in each formula will be substituted. This is an exercise of monetary integration.
\end{abstract}

Keywords: integration; income multiplier; money multiplier; velocity of money; and nominal income

\section{Introduction}

Money is the economic good that sees most movement, given its nature and purpose is to change hands in exchange for goods, services and financial assets. It is labelled a good as it represents all goods and it is exchanged for them. Its use is so widespread, which is the reason it was created, it has fascinated men in the street and seduced economic scientists to such an extent that it has been given diverse names according to its location and/or function. Names such as monetary base, money supply, money stock and hot money are used, in addition to others like aggregate demand and trading capital.

These latter statements may be heterodox, or at least rejected, as each concept has its place in the sciences and, depending on where it is found, in this case money, it will serve a function. This is the main aim of this study: to consider that diverse names hide a single concept and from them, create two categories: one category will contain the income and money multipliers and the velocity of money, which is another concept that is not exactly a multiplier. In the other category will be the results of the circulation of money, which are called nominal income, increase in nominal income, and money supply.

In summary: in all cases and paradigms money, its velocity and its result, which is nominal income, are addressed.

Money receives the names of monetary base, money supply and autonomous demand. This last name is referred to as money supply in this study. For all intents and purposes, demand is no more than the economic exercise for which money is handed over: money supply, in exchange for goods and services and/or financial assets. Given that what is handed over is money, it shall be called money supply for clarity.

The argument of this thesis will be challenged with the clear and strict critiques of professors Tobin and Samuelson.

\subsection{Tobin's Critique}

Tobin's answer to this study's proposition, in a letter (on letterhead from Yale University), was stark and unequivocal. In his letter, dated 13 May 1997, he answered: "I cannot agree with your opinion that the velocity of money is the same thing as the income multiplier. The income multiplier is the ratio of two flows: both of the same dimension in dollars (preferably in constant dollars) per year; therefore, this ratio is a pure number, the ratio of the GDP to an exogenous element of the GDP (e.g. government purchases and investments). The velocity of money is the ratio of a flow (GDP in dollars per year) to stocks (money stock in circulation). It is the dimension of dollars per year per dollar of money stock. Given that they differ in dimension, they cannot be the same thing." His reasoning is clear. 


\subsection{Samuelson's Critique}

In a letter on letterhead from MIT, dated 24 June 2002, Professor Samuelson rejected this study's proposal: "I fail to understand how the Keynesian Multiplier of 1936 and Fisher's quantity theory of $M V=P Q$ can be unified for the simple reason that they are two different paradigms."

He then went on to make a brilliant demonstration of each. At the end of a paragraph he states: "tautologically the identity of $Y \equiv P Q \equiv M V$ exists. The tautology of Fisher's exchange of 1911 led him to an empirical theory on full employment in 1911; the price level provides the exogenous money stock (M) with the quantitative theory if (1) the full employment of $Q$ is always maintained, and if (2) the usual velocity of money (Vt $\equiv V 1)$ represents a constant habit, and if (3) the existence of a constant money stock is exogenously defined: Mt $\equiv M 1$ therefore, the price level $(P)$ must be proportional to money stock. $P t / M \equiv V / Q$."

Therefore, what can be done against this well founded arsenal of professors Tobin and Samuelson? This study answers this question.

\section{The Three Paradigms of Monetary Circulation}

The three paradigms of monetary circulation are: 1) the velocity of money (V);2) the bank money multiplier or expansion of the money supply $(\theta)$; and 3 ) the income multiplier $(\alpha)$. An explanation of each will be given.

\subsection{The Issue of Inequalities}

\subsubsection{Inequality in Quantitative Theory}

The velocity of money $(\mathrm{V})$, the money multiplier $(\theta)$ and the income multiplier $(\alpha)$ are greater than one, which indicates that they lead to, between the multiplicand and the multipliers, a greater result. Therefore, $V>1, \theta>1, \alpha>1$. Note: the velocity of money (V) is a multiplier named velocity. It is a question of semantics.

In each case the result is greater than the cause. Therefore, it is clear that in the velocity of money, nominal income is greater than its cause which is money stock. To be more precise, this money stock, which circulates per unit of time, is money supply. Therefore $\mathrm{Y}>\mathrm{M}$. A further development can be made in this predicament, given that $\mathrm{Y}$ is nominal income or nominal result expressed in a monetary flow. Income $(\mathrm{Y})$ is a monetary flow per unit of time that exceeds its cause: the money supply. It can be estimated that the error or monetary myopia consists of changing from name to numbers. Following this line of thought, it can be confirmed that nominal income is superior to the initial money supply and this inequality is possible due to the number of times (the velocity) with which this money supply circulates, with each lap generating nominal income units. Thus $\mathrm{Y}>\mathrm{M}$.

\subsubsection{Inequality in the Money Multiplier}

Hypothetically accepting the creation of central bank money, which is called the monetary base (BM), it can be discerned that at the end of the period purchases were made at a superior value. Considering the instrument of these purchases, which is none other than money (a definition), must be explained, it can be concluded that money was created as otherwise it would be impossible to understand how these purchases were made. Final purchases are made with a quantity of money (M), which is, by definition called the money supply. There is no other evidence, given the money supply in the paradigms explained consists of two concepts: one is its nature or subject, which is the payment method (whether material or invisible) and which is money; and the other is its position or action, the act of handing it over or offering it, and as long as money is offered to make a purchase. In other words, money has been created and this is the money supply (M), and it is superior to the original payment methods, which is the monetary base (BM).

Therefore, it can be understood that $\mathrm{M}>\mathrm{BM}$. The previous statements on the volume of final purchases that are possible with the money supply are essential for the purpose of this study, which is the integration of the three paradigms $(\mathrm{V}, \theta, \alpha)$ in a unique phenomenon.

\subsubsection{The Issue of Inequality in the Income Multiplier}

Once an increase in autonomous demand $(\Delta \mathrm{A})$ - which could be consumption, investment, public spending or net exports (all autonomous) - occurs, an expansion of the nominal income $(\Delta \mathrm{Y})$ is generated, giving rise to the following inequality: $\Delta \mathrm{Y}>\Delta \mathrm{A}$. Each of these concepts will be analysed step by step.

For starters, autonomous demand implies two coexisting realities: a net increase of something and that something is the purchase. Secondly, a purchase means handing over or offering money in exchange for goods: if money is not handed over, a purchase is not made, whatever its nature. Therefore, why is this operation not given the correct name? 
Meaning, why is it not called money offered? In summary, autonomous demand is clearly different to money supply. An increase in autonomous demand is an increase in money supply. Therefore $\Delta \mathrm{A}=\Delta \mathrm{M}$. This is not merely a question of semantics, but a question of concept and, consequently from a macroeconomical and mathematical point of view, a tautology.

Therefore, the income multiplier can be defined in the following manner:

Given that $\Delta \mathrm{A}=\Delta \mathrm{M}$, it can be said that $\Delta \mathrm{M} \alpha=\Delta \mathrm{Y}$. This formula will not be particularly useful in integrating the three paradigms.

\subsection{The Parameters: Velocity, Money Multiplier and Income Multiplier}

In this section the equality or identity of what multiplies a variable will be addressed. These variables are the money supply, the monetary base and autonomous demand. In particular, the thorny subject of whether these parameters correspond to the same phenomenon, or if they are equals or equivalents, will be tackled.

\subsubsection{The Velocity of Money}

The quantity theory of money and the velocity of money is expressed in the following manner:

When the money supply $(\mathrm{M})$ offered circulates a number of times $(\mathrm{V})$ it is capable of acquiring a production quantity (Y). Therefore, this can be expressed as M.V $=\mathrm{Y}$.

If the monetary authorities or any exogenous movement creates money, initially it would be called the monetary base (BM). This money stock, upon circulating in the monetary system, is capable of acquiring a superior amount of goods and services and financial assets. The amount of money offered is called the money supply as it represents a quantity of payment methods that are sold, with this sale being the activity of making a purchase. Therefore, BM. $\theta=$ $\mathrm{M}$, with $\theta$ being the money multiplier. There is an inequality between the exogenous money that is initially in the system, which is the monetary base, and the money created, which is the money supply: $\mathrm{BM}<\mathrm{M}$. It is only possible for the initial money supply to be greater than the exogenous money, which is the monetary base, as said initial money, upon circulating, makes possibly greater purchases than the initial theory, as it is continually offering or purchasing.

There is another way to understand this phenomenon and it consists of substituting the idea of money creation, or the money supply, for the circulation of money, or better said, the velocity of money. This can be expressed as BM. $\theta=$ M. Therefore, the equation $M V=Y$ can be changed to BM. $\theta V=Y$. On the other hand, $V=1 / k$, leaving the following equation: BM. $\Theta .1 / \mathrm{k}=\mathrm{Y}$.

The subjects separate a proportion of income that will be spent $(\mathrm{k})$, with $\mathrm{k}<1$. Therefore, the average amount of money a person will have for spending will have the following value: $\mathrm{kY}$, with $\mathrm{Y}$ being the nominal income. Therefore $\mathrm{kY}<\mathrm{Y}$. This inequality shows that a) The average money stock set aside for purchasing is inferior to nominal income; and b) for the kY quantity to pay or finance the total nominal income (Y) it must circulate a number of times (V), or in other words acquire velocity. This is easily compared (it is a similarity) with the physical concept of the velocity of an object, which is the distance travelled divided by the time it takes to travel said distance. The distance would be the nominal income, which will be spent in fractions of $\mathrm{kY}$, and in order to continue, it can be said that income and production are quantitatively similar. Delving deeper, what is spent in its totality (nominal income) is what others produce and sell per unit of time, or rather a flow of production.

The initial formula is $M=k Y(1)$. Moving $k$ to the first side, the equation looks like $M 1 / k=Y(2)$ and given that $1 / k$ is the velocity of the money an individual has to make purchases, we are left with MV $=\mathrm{Y}$ (3). The money supply has had to circulate a number of times $(\mathrm{V})$ to acquire nominal production $(\mathrm{Y})$.

The concepts should be specified. What is M? Is it simply a money stock? The answer is an amount of money that is offered in exchange for goods and services recorded by Y. One of the most basic concepts of economic activity is the purchase and sale of goods and services, and both represent the same activity simultaneously. Germán Bernácer said that he who is selling goods is asking for money and he who is asking for goods is offering money. The money supply receives its name, as it must, because it is money and, above all, because it is offered or sold in exchange for goods and services.

In conclusion, if it is true that $\mathrm{M}$ is the money offered, $\mathrm{M}$ is money supply. Therefore, we can use this concept (M) and substitute it in the other equations that express the two other monetary paradigms: firstly, the money multiplier $(\mathrm{BM} . \theta=\mathrm{M})$ and secondly, the income multiplier $[\Delta \mathrm{A} . \alpha=\Delta \mathrm{Y}(4)]$. 


\subsubsection{The Money Multiplier}

Once new money is made and entered into the system, and which is named the monetary base (BM), it is possible to make a level of purchases superior to its initial absolute value due to the creation of bank money, which is money supply. It is called money supply as it is money that is offered for the act of purchasing. As the case to be considered occurs in banks, the corresponding parameter must be analysed, and this is the bank money multiplier, the formula of which is $\theta=(1+\mathrm{e} / \mathrm{e}+\mathrm{r})$. As the aim of this study is to figure out the nature of each parameter, in this case, the money multiplier is addressed.

Once the new money enters the system, new payment methods, or money, are fabricated and the majority are invisible, although this detail of invisibility is not relevant. One can imagine that, during each stage of monetary circulation income is generated. Every time money circulates it is because someone hands it over or offers it, therefore it is money supply, and the person who receives it is the money seeker, the person selling the goods he produces. Therefore, each money creation stage is a phase of income generation, and considering all stages, the total period means the total generation of income. Consequently, it is possible to confirm (and repeat) that:

BM. $\theta=\mathrm{Y}(5)$

However, a serious inconvenience arises here. It is known that BM. $\theta=\mathrm{M}$ and, due to the quantity theory, that M.V $=$ Y. How can this problem be resolved? Via the substitution of M into equation (2). This is not a forced discovery or creation, instead it is a request of principles with reasons:

1. It is true that money is multiplied.

2. It is true that nominal income is also multiplied.

3. Nominal income is a monetary flow per unit of time.

Consequently, it is perfectly appropriate to dismantle the belief that says money circulates and is fabricated without generating nominal income, in addition to rejecting the belief that nominal income is generated without money being manufactured. What should be done? Formula (2) should be integrated into formula (5):

BM. $\theta . \mathrm{V}=\mathrm{Y}(6)$

This indicates that all the circulating money, the money supply $(\mathrm{M})$, circulating a number of times $(\mathrm{V})$ finances a given level of nominal income (Y) during the period. This can also be expressed as BM. $(1+\mathrm{r} / \mathrm{e}+\mathrm{r}) . \mathrm{i} / \mathrm{k}=\mathrm{Y}(7)$

From here, it can be confirmed that the traditional equation of $M V=Y$ has an inferior value to that of equation (7). It is easy to discern that with $\theta \cdot \mathrm{V}=\mathrm{V}$, with $\theta>1$, the following inequality is generated:

BM. $\theta . \mathrm{V}>\mathrm{M} . \mathrm{V}(8)$

In summary:

1. If the reality in which the creation of money supply and the velocity of said money are combined is observed, a level of income can be financed, the authentic higher level of nominal income. How much higher? In a higher proportion than if only the velocity of money were to be considered. In short, as a money supply (M) circulates in this same process, money is created, a greater level of nominal income can be generated than if only the velocity of money were considered.

2. This stance differs to the orthodox or usual approach (that of $\mathrm{MV}=\mathrm{Y}$ ) in which the bank money multiplier intervenes, in which money is inevitably created. Any contrary assertion (such is the heterodox) is an error. How can this be differentiated from the quantity theory? To do so, suppose that Mo is the amount of orthodox money and that $\mathrm{Mn}$ is the total amount of money created, this is the starting point, added to the new BM. $\theta=\mathrm{Mn}$. The new amount or added money will be:

$\mathrm{Mn}-$ Mo.

Observation: At this point a question can be raised. Given that in the orthodox case (MV $=\mathrm{Y})$ there will be an increase in the liquidity preference or a demand for money for transactional reasons, and as there is no creation of money, will there be an increase to the interest rate? The answer, according to this point of view, is negative as there is a new money supply because money is being created.

\subsubsection{The Income Multiplier.}

The income multiplier implies that, considering an increase in initial spending $(\Delta \mathrm{A})$, a summation chain of incited costs superior to the initial cause is the result. The aforementioned will be commented on from another perspective. Suppose that during each stage of sale and purchase there was an added production and therefore an added income. 
Viewed in this way, there will be a chain of added sums of nominal income and its final result or sum is $\Delta Y$. This summation is a decreasing geometric progression of reason $1 / \mathrm{s}$, with $\mathrm{s}$ being the marginal propensity to save. Therefore, it is clear there will be a parallel chain of filtration in saving, meaning the summation is not indefinite. The formula is then $\Delta \mathrm{A} . \alpha=\Delta \mathrm{Y}$, with $\alpha=1 / \mathrm{s}$.

Previous sections have shown that $\Delta \mathrm{Y}>\Delta \mathrm{A}$. Two realities that are as true as money and the successive acts of buying and selling will now be considered:

1. The increase in spending implies an increase in money that is offered in exchange for goods and services that are bought. And what is the money offered if not money supply? Here, macroeconomics, in its great effort to define it, has provided two names for the same act: increase in autonomous demand, and increase in money supply. It would be dangerous to say they are equals; however there is only one reality, one single operation, and that is an increase in the money supply $(\Delta \mathrm{M})$.

2. The money that is offered and which propagates in the economic system in the form of autonomous demand creates money. In order to support this affirmation, the formulation from previous sections - which says that an amount of monetary base, as it circulates, creates money according to the money multiplier - will be used. Previously it was stated that $\mathrm{M}=\mathrm{BM} . \Theta$. Y, and working with increases such as autonomous demand and the money supply leaves $\Delta \mathrm{BM}=\Delta \mathrm{M}$.

Conclusion: substituting the increase in autonomous demand $(\Delta \mathrm{A})$ for its monetary formulation $(\Delta \mathrm{M})$ (they are not two different realities, instead they are the same thing) leaves:

$\Delta \mathrm{BM} . \theta \alpha=\Delta \mathrm{Y}(9)$

Here, another inequality can be discerned:

$\Delta \mathrm{BM} \theta<\Delta \mathrm{BM} \theta \alpha$

What does this new inequality mean? It means the following:

1. Nominal income grows more if the money multiplier intervenes.

2. This superior growth is owed to the fact there is new money added to the system. This new money is above what the new entry of money supply implies in the form of added autonomous demand.

3. If only the income multiplier $(\alpha=1 / \mathrm{s})$ is used, which is the usual orthodox explanation, the initial money supply intervenes and nothing more. This is not true as money, upon circulating in the operation of the chain of buying and selling and generating income, inevitably creates money.

4. Mathematically, the affirmation of this study can be supported via the intervention of the income multiplier and the bank money multiplier, as seen here:

$\Theta \alpha>\alpha$

This is due to the fact that each multiplier is superior to the unit, and that the two multipliers when multiplied are superior to the income multiplier if only one $(\alpha)$ were to intervene, in this case the income multiplier.

5. There is another argument that acts on the goods and services market in the known investment/saving (IS) curve along with the money market and financial assets in the liquidity-money (LM) curve. Once the autonomous cost multiplies the nominal income, a displacement of the IS curve to the right occurs. Like in the orthodox (usual) example, nothing happens in the expansion of the money supply: the LM does not move. However, it is true that there is an increase in the demand for money (cash) to finance new purchases of goods and services and that financial assets are sold off, hastening its fall $(--\Delta \mathrm{V})$ and increasing the interest rate $(\Delta \mathrm{r})$. This means that the increase in money due to transactional reasons on a theoretically constant money supply raises the price of money, with this high price appearing due to the increase in interest rate. Graphically, this can be viewed via the displacement of the IS on an immovable LM.

This reasoning is false. It is true that the IS is displaced, but it is also true that it increases and displaces the LM to the right due to the growth of money while the interest rate should not increase, or if it does, it does so gently.

Note: The interest rate would be inclined to remain constant as long as the money multiplier and the income multiplier tend to be equal. As both are measured by their denominators, there would be equilibrium provided that the bank reserve ratio is equal to the marginal propensity to save. 


\subsubsection{The Income Multiplier and the Velocity of Money}

There is a problem here. As Professor Samuelson stated, there is a money supply or stock that circulates a number of times $(\mathrm{V})$ to make purchases, with the sum of all of these purchases being the general increase in nominal income. It should be emphasised that neither the bank reserve ratio nor the marginal propensity to save is involved in the paradigm. Therefore, there is no filtration. Consequently, it can be affirmed that the income multiplier, by definition, is neither the money multiplier (the filtration of which are bank reserves) nor the income multiplier (the filtration of which is the marginal propensity to save), as will be discussed in section 3. The paradigm of quantity theory cannot be forced as heroic as it implies the unreality that neither income nor money is multiplied, in both cases during the period.

The question is that, despite the inequalities noted in previous sections, logical (and not merely semantic) incorporations have been made. What will be done in this section? It is difficult to answer, as these issues are hard to define. For example, if the quantity theory is applied to the paradigm of the income multiplier, filtrations (S) occur in an example where, in principle, there are none.

\section{The Equality of the Multipliers}

This section shall consider the velocity of money $(\mathrm{V})$, the money multiplier $(\theta)$ and the income multiplier $(\alpha)$ and analyse their similarities and differences. In order to make these comparisons, two cognitive considerations must be taken into account. The first is conceptual: what is being considered? This is, in essence, what is of interest. The second is quantitative.

First, the similarities shall be critiqued:

3.1 The multipliers (including the velocity of money [V]) establish a causal relationship between a money supply and its final result or net effect, which is superior to its cause.

These effects are:

3.2 In the quantity theory $(\mathrm{Y}>\mathrm{M})$, or when the nominal income is superior to the initial cause. In both cases, money is used, but nothing indicates they should be considered the same economic parameters. Money is one thing and the other is nominal income, although the latter is measured with the unit of measurement that is money. Here, the velocity of money (V) establishes a relationship (superior to the unit) between a money stock or money supply and the level of nominal income. This is a concept that calculates the times that a monetary unit passes from person to person in buying and selling processes.

3.3 The bank money multiplier establishes a relationship between the final money or money supply and the money that enters the system or monetary base. As more purchases can be made in the system than the money that enters it, this difference is called the money supply. In other words $\mathrm{M}>\mathrm{BM}$. Here, a relationship is established between the monetary base and the money supply. In principle, it is similar to the velocity of money as a variable (the money supply) is found in the two inequalities, $\mathrm{Y}>\mathrm{M}$ and $\mathrm{M}>\mathrm{BM}$, and for now it can be affirmed that $\mathrm{Y}>\mathrm{BM}$.

Now, focus is shifted to the issue of interest: the paradigms. The velocity is the inverse of the liquidity preference (V $=1 / \mathrm{k}$ ) and said preference is a proportion that is used to finance a level of nominal income. Another, different reality is the bank money multiplier $(1+\mathrm{e} / \mathrm{r}+\mathrm{e})$, which, in principle, has nothing to do with the liquidity preference. This preference goes directly to spending, while bank reserves are separated from the banking system and frozen. It can be concluded that these two paradigms, the velocity and the multiplier, are two different paradigms.

As for their numeric value or monetary measurement, they are different as their purposes or concepts differ. For example, a level of bank reserves of $10 \%$ can be maintained due to the decisions of the monetary authorities, and individuals can maintain a liquidity preference of $15 \%$, with the reason being that their purposes are distinct by definition.

\subsection{In the Income Multiplier}

The income multiplier $(\alpha)$ is the inverse of the marginal propensity to save $(1 / \mathrm{s})$. In other words, as income is spread by spending, there will be filtration measures in a proportion of the income (s.Y.) which converts it into a decreasing geometric progression of reason $1 / \mathrm{s}$. Now, this indicates the degree in which the nominal income is expanding. This is similar to the velocity of money, but this insistence should be immediately resisted as saving (sY) or its proportion (s) is not spent (which is why it is called saving), while preference (k) or its value (kY) have final spending as their aim. Therefore, they are conceptually opposed. 
Observation: The following concern has not gone unnoticed. Isn't the money that is maintained to finance the nominal income, in this period - the liquidity preference $(\mathrm{kY})$, waiting to be spent - a saving on spending from one period to another? In short, the money that is maintained for spending, in said situation, is a type of transitory saving.

Another supposed similarity is addressed: the income multiplier and the bank money multiplier. One operation, and therefore concept, is the marginal propensity to save (s) and another is the proportion of reserves in relation to banking deposits $(1+\mathrm{e} / \mathrm{e}+\mathrm{r})$. Their purposes, their implementation and their nature are different. Accepting these differences, their numerical value will also be different. If there were an equality between $\alpha=\theta$, the income multiplier and bank money multiplier, there would be agreement.

It is here where the next reflection is made: a bank can believe that, supposing that banking laws and regulations do not require them to maintain reserves for security, prudence or other reasons, it would be in their interest to maintain a level of savings in the bank (r) and another in active money (e). What is the difference? There is no difference. What is more, it would force the specification and decision to remain with two equal multipliers. There would be no conceptual difference between the two aforementioned multipliers. There would be a similarity and an identity.

\section{Bernácer's Theory of Equilibrium}

In this section, Bernácer's theory of monetary equilibrium will be introduced in the context of the monetary forces previously developed. It has been explained in several books and articles that Bernácer did much more than create or found macroeconomics in 1916 with Sociedad y Felicidad. Un Ensayo de Mecánica Social.

Our researcher affirmed that, in the macroeconomic system, there were two circulating capitals and, according to their magnitudes, new money would be needed in the system. The destination will conclude with the equality between new money $(\Delta \mathrm{M})$ and new circulating capital $(\Delta \mathrm{CC})$, that is:

$\Delta \mathrm{M}=\Delta \mathrm{CC}$

"y afirmaba que el equilibrio sólo es posible cuando a un aumento (o disminución) corresponde una variación equivalente en la cantiad de moneda circulante, resultado que, en su simplicidad, tiene una gran importancia para interpretar los hechos económica del capital circulante" (La Doctrina Funcional del Dinero, 1945. Germán Bernácer)

[and this affirms that equilibrium is only possible when an equivalent variation in the amount of circulating money corresponds to an increase (or decrease), a result which, in its simplicity, is of great importance in the interpretation of the economic acts of circulating capital]

Said circulating capitals, according to the accountant from Alicante, are of two types: the first class circulating capital is the sum of the added values in production and which determine the final product. It will be measured by the segment, ah (following Bernácer's nomenclature). This volume of production is destined for consumers.

On the other hand, payments that are made between business people for intermediary products in a period are also included. Note: This does not mean that these payments are final production, as they would be the equivalent of adding up the same production several times. It is denoted as Y.

If the first class circulating capital is expressed as ah and if it is final production, and if payments between companies are expressed as $\mathrm{Y}$, such that $\mathrm{Y}>$ ah, then the second class circulating capital would be worth $\mathrm{Y}-\mathrm{ah}$, and it is in this magnitude in which new money would be necessary. Said amount of new money will enable payments to be made by consumers and companies. This explains, with perfect logic, that said financing of first class circulating capital was made with savings, so there would be two supply volumes in the market: one would be the old production that has not been removed from the market for the formation of savings, and the other would be of new production. However, there would be a single demand to withdraw one or the other, but not both. The need to create new money is obvious.

For now, Bernácer's theory is left to one side and this study's unifying monetary conception is applied:

1. The unifying theory is applied, especially via the introduction of the money multiplier: $\Delta \mathrm{BM} \theta=\Delta \mathrm{M}$.

If $\Delta \mathrm{M}=\Delta \mathrm{CC}$, then $\Delta \mathrm{BM} \cdot \theta=\Delta \mathrm{M}$

The merit of Bernácer's work should be recognised. From the outset, he rejected slavery to the gold standard, which artificially and efficiently oppressed the growth of the real magnitudes and opted for fiduciary payment instruments. 
2. When is the process of real first class capital growth, which is to say the final domestic production, stopped? To understand this, the beginning of an initial spend process that has been aided with new money will be used. This is the income multiplier with an increase in initial autonomous spending $(\Delta \mathrm{A})$, however much. That is, $\Delta \mathrm{A} . \alpha=\Delta \mathrm{Y}$.

However, reasoning has shown that said autonomous spending has, by nature, money or the money supply in its multiple forms. Better said, as the expansive income multiplier effect process develops, money is created, which enables a greater expansion of income to what was initially estimated. Substituting (in reality equalling) the increase in autonomous spending $(\Delta \mathrm{A})$ with the increase in the money stock $(\Delta \mathrm{M})$ and multiplying the two multipliers (the income multiplier with the money multiplier), the result is the expansion of the final income. Given that the final income is the circulating capital:

$\Delta \mathrm{A}=\Delta \mathrm{M}$

$\Delta \mathrm{M}=\Delta \mathrm{CC}$

$\Delta$ BM. $\theta . \alpha=\Delta$ CC

This is a part of this study's question that has been resolved. Moving to the fundamental equation $(\mathrm{S}=\mathrm{I})$, supposing that the role of third degree net availabilities is neutral, from a static viewpoint, saving would be equal to investment. Everything changes dynamically as the need to create money, or money supply, is necessary to finance the total of circulating capital.

$\mathrm{S}+\Delta \mathrm{M}=\mathrm{I}+\Delta \mathrm{CC}$

Introducing the monetary base and the money multiplier, it would look like:

$\mathrm{S}+\Delta \mathrm{BM} . \Delta \theta=\mathrm{I}+\Delta \mathrm{CC}$

This process of creating money, which symbolises wealth, is necessary to generate the flow of goods and services or to finance the transactions in the system, which is effectively the same thing. This process means that new domestic production and demand is facilitated. Therefore, the meaning of wealth (money), whatever the form it acquires, will be represented by the new flow of goods and services, which signifies price stability.

\section{Conclusion}

There are three phenomena that imply the existence of money as a flow and nominal income, in addition to the creation of money supply. Money flows make it possible for there to be a cause, which will always be money, and which generates a superior monetary effect. The monetary base, which is money, upon entering the banking circuit as a flow provokes an expansion of the circulating money or numerically greater money supply. In the event money stock circulates a number of times (V), it enables the financing of a greater nominal income. If there is an increase in aggregated demand - and it is nothing more than an increase in the purchasing money supply - the multiplier makes a greater expansion of the nominal income possible.

In all cases, the money supply and the phenomenon of the money that circulates or multiplies act. In each and every case, it is hoped that whether they correspond to the same phenomenon or not will be resolved.

\section{References}

Bernácer G. (1916). Sociedad y Felicidad. Un Ensayo de Mecánica Social.Madrid, Editorial Beltrán Heredia. (1925). Interés del Capital. El Problema de sus Orígenes. Alicante, Editorial Lucentum.

(1941). La Teoría Monetaria y la Ecuación de Mercado. Madrid, Anales de Economía, 35-71

Baumol W. (1967). Business Behaviour, Value and Growth (2nd ed.). New York.

Cassel, G. (1901). The Nature and Necessity of Interest. Londres.

Friedman M. (1969). The Role of Monetary Policy. Atlantic Economic Review. (1974). A Theoretical Framework for Monetary Analysis. Journal of Poskeynesian Economic, 78, 193-238. 
Hicks, J.R. (1982). Mr Keyne's Theory of Employment. Economic Journal, 46, 238. http://dx.doi.org/10.2307/2225227

------- (1947). Mr. Keynes and the Classics: a Suggested Interpretation. Econometrica, 5, 147-59,

Keynes, J., M. (1936). The General Theory of Employment, Interest and Money. Londres: McMillan.

Laidler, D. (1969). The Demand for Money. Theories and Evidence. Dun-Donnelley Publishing Corp.

Leivojonhufvud, A. (1968). On Keynesian Economics and the Economics of Keynes. Oxford: Oxford University Press.

Lucas, R. E. (1972). Expectations and the Neutrality of Money. Journal of Economic Theory, 4, 103-124. http://dx.doi.org/10.1016/0022-0531(72)90142-1

Patinkin, D. (165). Money, Interest and Prices (2nd ed.). New York: Harper and Row.

Samuelson acarta del MIT contestando a nuestra propuesta fechada el 24 de junio de 2002.

Tobin, J. (1997). Carta desde Yale University contestando a nuestra propuesta fechada el 13 de mayo de.

(1947). Liquidity Preference and Monetary Policy. Review of Economic and Stadistics, 29, 124-131. http://dx.doi.org/10.2307/1927887

Villacis José. (2015). A Unified Theory of Monetary Dynamics. International Journal of Engineering Technology and Scientific Innovation (IJETSI), 1(2), 8.

- La Teoría del Interés y del Dinero en Germán Bernácer, Revista de Hacienda Pública. Instituto de Estudios Fiscales. Madrid pp 167-1931983.

-------- (2005). Companies Prefer Liquidity. The Business Review, 3(3), 253-264.

--------- (2005). Production and Macroeconomic Equilibrium. The Business Review, 3(2), 335-340. 